\title{
E.S. Markarian's Traditiology: Distinction from Foreign Tradition Theories
}

\author{
Svetlana V. Lourié* \\ Sociological Institute of the RAS \\ 25/14, 7th Krasnoyarmeyskaya Str., \\ St. Petersburg, 190005, Russia
}

Received 04.04.2016, received in revised form 28.05.2016, accepted 19.07.2016

E.S. Markarian's traditiology is considered in the article against the background of foreign tradition theories by R. Redfield, A. Royce, E. Shils and S. Eisenstadt. All Western authors who wrote about tradition, one way or another base on the dichotomy of "tradition-modernization" what is not typical for Russian scientists. Tradition itself for them is a mechanism for the development of any society. S. Eisenstadt's tradition theory, as well as E.S. Markarian's traditiology assumes variability of tradition, the presence of creative component in it. The difference lies in the fact that Markarian's tradition itself has a mechanism of self-development, and development is a natural characteristic of tradition and acts, in turn, as a mechanism for the development of society. Markarian's traditiology describes the world volatile in its nature and a conservative component of tradition in the works by Markarian is paid much less attention. Markarian closely links traditiology with his theory of adaptation and activity approach in culturology. Markarian's traditiology is convenient as a theoretical justification of ethnology tools that allows to observe what in culture is permanent and what changes, and how. The history of Soviet and Russian traditiology is considered in the article as well.

Keywords: traditiology, the dichotomy of "tradition-modernization", a historical style, conservative and creative components of tradition, novation, innovation, self-development, adaptation theory, the activity approach.

DOI: 10.17516/1997-1370-2016-9-8-1719-1726.

Research area: culture studies.

The doctrine of tradition - traditiology, as it was called by Eduard Sarkisovich Markarian, who, in fact, created this new research area, is an integral part of Russian culturology and ethnology. What is the peculiarity of Russian traditiology? Its main characteristic is that Markarian's and related to him philosophers-cultural studies scholars and anthropologists's tradition is a variable and live category that forms not only in the past, in history, but in front of our eyes. The concept of "tradition" in equally referred both to the present and the past. The variability of tradition and the presence of creative component in it are also found in some foreign conceptions of tradition. Let us consider in what way Russian traditiology is different from the foreign vision of tradition and, at the same time, study how it was originated.

(C) Siberian Federal University. All rights reserved

* Corresponding author E-mail address: svlourie@gmail.com 
Up to the 60 s of the $20^{\text {th }}$ century scientific view on the concept of "tradition" in the West was determined by the approach that was formulated by Max Weber and boiled down to the harsh opposition of the categories of traditional and rational, tradition and modernization. Traditional institutions, customs, and the way of thinking were seen as an obstacle to the development of society. In fact, the researchers' interest was focused on the issues of modernization and due to this the traditional features were mainly determined in negative terms, as an opposition of modernization. In terms of this approach, the processes of modernization always undermine, weaken and replace tradition. Tradition is seen as a fading phenomenon, unable either resist any modern forms of life, or co-exist with them.

However, in the early $60 \mathrm{~s}$ of the $20^{\text {th }}$ century the view on tradition as a stiff form was called into question. It was done, first of all, not by the modernization theorists, but countries experts (orientalists and Africanists), who, in the course of their field work, directly studied the very societies that were usually called traditional [see, for example. Rudolph, Rudolph, 1967]. A number of theoretical studies on general issues of modernization appeared. They laid the foundation of a comprehensive and profound criticism of this theory, and above all, the thesis of the traditional society statics. A transition from the static perception of tradition to its dynamic consideration takes place. In particular, the concept of "transitional society" appeared (Riggs, 1964).

However,manyauthors, essentiallyrecognizing the legitimacy of the new views on the problem of tradition, preferred to retain old meaning of the term "tradition", as something inert and conservative, or even completely decline this term, and used other terms to describe the "transitional" states of society. For example, American ethnologist Anya Royce offers the concept of "historical style", which is "based on common cultural parameters and values"
(Royce, 1982: 137), while remaining flexible and diverse. Both social forms, gone into the past, and modern social forms might be interpreted as external manifestations of plastic and flexible "historical style".

Others researches preferred to retain the term "tradition" itself, but in its meaning it still turned out to be close to what Royce called "historical style". Thus, Edward Shils' approach, according to which "following tradition, in fact, is implementation of different variations on the theme perceived from previous generations" (Shils, 1981: 13), is almost classical. Tradition for Shils is not "something self-generating and selfelaborating. Only a living, knowing and having desires human being can perceive and modify it" (Shils, 1981: 15). Thus, tradition, although flexible and variable, is not an active and creative essence. Earlier Shils introduced into his teaching about the culture and tradition a very fruitful conception of a "central zone" of culture - the "unchanging core of culture, consisting of values and beliefs, around which flexible and changeable cultural "periphery" is concentrated" (Shils, 1961: 117). This two-leveled structure also assumes arbitrariness of changes and connects them with the conscious activity of man. Thus, tradition is what people can change at their will, without breaking it, if, at that, they do not encroach on the values and beliefs inherent in it.

But, of course, the most original (and the most popular in Russia) of the foreign authors, who wrote about tradition is Shmuel Eisenstadt. According to Eisenstadt, tradition is "an essential element of any social culture as any social organization in general (whether it is so-called traditional or modern society), and each of its elements separately" (Eisenstadt, 1973: 124). Eisenstadt focuses on the relations of tradition and charisma in society, analyzing the "charismatic appeal" and the nature of the social situation, when people become particularly sensitive to such an appeal. 
And both the charismatic action and the action undertaken within the framework of tradition are characterized by a specific conception of the ideal order of things, a certain ideal structure that allows cultural models to flow from the charismatic sphere into the traditional one and to stabilize and institutionalize there. Creative ones, associated with charisma and stabilizing elements, are closely intertwined in tradition.

Like all the Western scholars who wrote about the issue of tradition, Eisenstadt is also interested in the dichotomy of "tradition-modernization". But addressing the problems of modernization Eisenstadt notes that it would be incorrect to contrast traditional and modernized societies (Eisenstadt, 1992: 139). This is because, in this case, we would have to split tradition into separate components and proclaim that one of them (conservative) is characteristic of "traditional societies", and the other one (creative) - of modernized ones. For Eisenstadt it was important to demonstrate that "modernity" is also a special case of tradition and specific internal contradictions are inherent in tradition itself. Eisenstadt illustrates this thesis by the concept of Great tradition (traditions of universities and temples) and Little tradition (traditions of the village community), coexisting within a single culture (see. Redfield, 1956). Eisenstadt considers the first as a synonym to the desire to expansion, and the second as the desire for institutionalization. Latent or evident confrontation of these two traditions contributes to the development of society, provoking more and more changes. Little tradition serves as a "determinant of the limits of innovation and the main criterion for their legitimacy" (Eisenstadt, 1992: 51-52).

It seemed that Eisenstadt's ideas partially affected foreign sociology. Popular modern sociologist Peter Sztompka, for example, wrote: "Any tradition, regardless of its content, can restrain creativity and innovations" (Sztompka,
1996: 96). In practice, Eisenstadt, unfortunately, absolutely did not affect Western ethnology and anthropology. Foreign ethnologists and cultural anthropologists rarely resort to the notion of "tradition", or rather, use it only in the narrow sense, close to the notion of "custom". They have never set the task to study the phenomenon of tradition, though paid a lot of attention to the study of the so-called traditional society.

Understanding creativity and flexibility of tradition makes Eisenstadt popular in Russia and brings his teaching on tradition together with the Russian traditiology and ethnology. Running ahead, let us mention, that the latter, opposed to the Western one, willingly responded to traditiology, though initially it was domestic, Markarian's traditiology.

$* * * * *$

Before turning to the relation of ethnology to traditiology we will say a few preliminary words about Eduard Sarkisovich Markarian' teaching about tradition.

Markarian considered tradition as overbiological mechanism of social life organization, considered by him "as the functional evolutionary equivalent of cellular organization of biological life" (Markarian, 2014: 486). But for our topic, not the elements of evolutionism in Markarian's conception, which from the point of view of traditiology application in ethnological studies can be taken off the table, are important. It is of paramount importance that Markarian's tradition:

- is considered as fundamentally flexible: "I understand traditiology as a science of the class of traditional phenomena, laws and mechanisms of their dynamic transformations" (Markarian, 2014: 477),

- is defined as "any collective (group) stereotype of activity, based on learning activity" (Markarian, 2014: 479), 
- is understood as a mechanism of culture. Culture "is a specific way of people's social life self-organization, a universal technology of human activity", and "cultural tradition is one of the means of culture ... which, covering the whole system of culture, literally penetrates into all its "pores". As collective stereotypes of human activity, cultural traditions, considered in their dynamics, appear as carriers of a number of extremely important universal (within society) functions of social evolutionary self-organization" (Markarian, 2014: 484).

When Markarian's traditiology was presented to the Soviet ethnologists, it became clear that for many of them the idea of tradition inflexibility has always been nonsense as well. This was somewhat unexpected. As well as in the West, where the opposition "tradition - modernization" originated from the progressivist vision of history, where the development of society is made up of well-defined stages, and especially in the USSR, with its communist ideology, "tradition" should have been attributed to the past. And according to Markarian, it appeared that tradition is a universal mechanism for the society functioning, "Even today cultural tradition continues to be a universal mechanism, which, due to the selection of life experience, its accumulation and space and time transmission allows to reach stability, necessary for the social organisms existence. Without this mechanism, the social life of people is inconceivable ... Common nature and functions of these forms [the forms of traditions in the past and the present], the mechanisms of their formation and replacement remained basically the same" (Markarian, 1981: 87). In 1984, Markarian proposed conceptual theses of traditiology as a science for ethnologists' consideration. An interdisciplinary seminar, which materials were published as a discussion in several issues of the journal "Soviet Ethnography" in the same year, took place in Moscow. In the final to this discussion article Markarian first used the term "traditiology".

In wide discussion of this article the aforementioned theses of traditiology were seriously challenged by no one. There were debates about the terms: whether the term "tradition" should be understood in the broad sense or it would be more reasonable to continue referring the word "tradition", in the old-fashioned manner, only to customs and rites (however, the phenomenon described by Markarian was not disputed). But as soon as the wider meaning of the word "tradition" was accepted, it immediately turned almost into a synonym of the word "culture". Thus, K.V. Chistov developing a theoretical approach by Markarian, wrote: "The term "culture" refers to the phenomenon itself, and "tradition" to the mechanism of its functioning. Put simply, tradition is a network (system) of links of the present with the past, and using the network a certain selection and experience stereotyping are made" (Chistov, 1981: 106).

However, it should be noted, that Markarian firstly referred to the theory of tradition in 1977 in the book "Integrative Tendencies in the Social Sciences Interaction" (Markarian 1977: 187-204). And almost immediately the theory of tradition was proposed for discussion in the ethnological context at symposium "Methodological Problems of Ethnic Cultures”, held in 1978 in Markarian's native town in Yerevan, de facto - in one of the main centers of cultural studies in the Soviet Union and de jure - on the outskirts of the Soviet academic world, where sometimes greater degree of freedom than in the center was tolerated. It was at this conference where the idea of the necessity to create a general theory of cultural tradition was suggested for the first time, and its subject boundaries were outlined. Tradition was defined as "a mechanism of self-preservation, reproduction and regeneration of ethnic culture", as a system, which includes "the process and the 
results of stereotyping as a concentration of social and historical people's experience" (Abramian, 1978: 93). Thus, tradition is understood as one of the mechanisms of the society change!

Discussion in "Soviet Ethnography" made traditiology not only the subject of extensive debate, but also completely legalized it, introduced it into the range of topics that a Soviet scholar could study officially!

Thus, naturally, as of something self-evident, Russian cultural experts and ethnologists spoke of multiplicity of traditions, "a lot of connections were revealed between local, national traditions and common to humanity forms of life... The boundary between tradition and society was noticeably erased" (Sokolov, 1981: 43). It was concluded that "it is important not to oppose the innovation of tradition in general, but consider it as one of the parts of the mechanism of tradition functioning that is dialectically opposed to the part stabilizing it..." (Vlasova 1981: 112).

Thus, tradition is something that is in constant motion and change; and the source of this motion is in itself. It "serves as the core of the process of social self-organization ... The dynamics of cultural tradition is a constant process of overcoming some kinds of socially organized stereotypes and formation of the new ones" (Markarian, 1981: 80-81). In this case it is important to emphasize that the focus is made on the conception of social self-organization, and tradition is understood as its basis. In 1992, E.S. Markarian wrote: "The study of tradition should primarily occur in accordance with the fundamental principles of self-organization" (Markarian, 1992: 157).

$* * * * *$

This interpretation of tradition that emerged in the early $80 \mathrm{~s}$ of the $20^{\text {th }}$ century in the Soviet Union was the closest to the understanding of tradition abroad by Eisenstadt, who devoted a lot of works to the study of the principles of tradition formation and change. However, it is necessary to highlight some nuances, relevant in our opinion, that distinguish understanding of the term "tradition" in the Soviet Union from its understanding by Eisenstadt. And we will focus not on the "details", although very important ones (as there is simply no place for this in this article), but on the general spirit of these approaches, or, if you will, on their phenomenology.

First of all, Russian cultural studies scholars had never worked within the dichotomy of "tradition-modernization", for them tradition is obviously a contemporary phenomenon as well. It is striking that for the Soviet (later Russian and Armenian) authors the process of tradition development and replacement of some stereotypes with the others is as natural and seamless, as the flow of the river and the cycle of day and night. For any Western author and for Eisenstadt in particular, variability of tradition is something that needs evidence, and he resorts to this evidence, using a rather complex scientific apparatus. Eisenstadt cannot do without resorting to Weber's interpretation of tradition and the idea of a well-established tradition in the West, even by contradiction. But the Soviet scientist writes about variability and flexibility of tradition as if talking about a trivial and every obvious thing: "Any tradition is a former innovation, and any innovation is potentially a future tradition. In fact, no characteristic of tradition is originally inherent to any society, it has its origin and it appeared from somewhere, therefore, once it was an innovation. And what we see as an innovation will either not be established in the culture, wither away and be forgotten, or will be accustomed and over time will not look as an innovation, and hence become a tradition" (Arutiunov, 1989: 160).

For the Soviet authors tradition is a fundamentally dynamic and self-developing phenomenon. However, with this easiness and 
naturalness of the forms overflowing, which the Soviet science seemingly describes, the process of the "overflowing" is of greater interest to the Soviet scientists than the Western ones, at least, in those aspects of culture that are not material. For Russian researches, tradition itself is a mechanism for the development of culture and society. Thus, E.S. Markarian, reflecting on the issue of dichotomy "traditionvariation", believes that researchers face a lot of theoretical difficulties because they confuse "the concept of "novation" (novelty) and "innovation" (introduction). In the scientific tradition of the English-speaking countries, the term "novation" is not specified at all. Meanwhile, it may be said, that the distinction between these concepts is of key importance in understanding the dynamics of tradition. The fact is that the mechanism of this dynamic supposes a clear differentiation of the two states of experience - first is novelty and second is an adopted (by individuals or groups), stereotyped experience. Innovation refers to the second state that expresses the initial stage of the tradition formation. Thereby, it belongs to the social class of the traditional (but not actually novelty) phenomena" (Markarian, 1989, 35).

Thus, Soviet and Russian traditiology includes a representation of the world as of constantly developing and dynamic world by its very nature. It is possible to say that tradition itself is a mechanism for society changing. The emphasis is made on the creative (using Eisenstadt's terms) component of tradition, although its conservative component is often, alas, neglected. While the conservative component of tradition, being included into the mechanism of tradition self-development, becomes a component part of creativity. Otherwise creativity would remain only some form of "bad" variability, if it also did not contain conservation of such creative intentions that are able to bring changes to the "mature" state, without violating so much-needed social stability.

This approach to traditiology, when applied to history or ethnology, leads to the understanding of society as constantly changing. This approach is very productive, since it allows to emphasize exactly what cannot be changed, what remains constant for a given society and a given culture in social and cultural life. This approach, when applied to the empirical material, makes it possible to understand what is flexible, and that is constant in the society and in the culture of people; what being present in the culture at all time of its existence and in all its varieties for a long time, even for centuries, and what changes and how.

The connection of Russian traditiology with adaptation theory and activity approach in culturology, which is very characteristic of Markarian and his followers, should be noted. Markarian was developing the understanding of culture as a specific way of human activity, the way of people's existence with an adaptive nature.

Eduard Sarkisovich Markarian's statements concerning the connection of tradition with human activity has already been given above. We will complement them with his own words, "... Cultural traditions form the core of the whole system of stereotypes of human activity... By the reproduction or modification of this experience, traditions reproduce and modify the social life of people itself" [Markarian, 2014, 486]. This approach is important for ethnology, since what defines the distinctness of ethnic culture refers specifically to the stereotypes of action, if we understand the latter widely (and in traditiology they are understood in this manner), including their psychological background, among other things, and unconscious too.

Ethnic cultures, according to Markarian, represent historically developed ways of activity, 
due to which adaptation of various peoples to the conditions of surrounding them natural and social environment provided and is still providing (Markarian, 1978: 8-9). This, primarily, is the function of culture as a specific means of human adaptation (Markarian, 1998: 84). But what prevents affirming that human environment is filled with "instruments and tools" of human behavior for adaptation, and activity including "sets" by orientations too and that also existing at psychological or ideal form? And this is a necessary premise to develop ethnology, ethnological psychology and psychological culturology on the basis of traditiology.

\section{References}

Abramian, E.G. (1978). Innovatsiia i stereotipizatsiia kak mekhanizmy razvitiia etnicheskoi kul'tury [Innovation and Stereotypization as the Mechanisms for Ethnic Culture Development], In Metodologicheskie problemy etnicheskikh kil'tur: Materialy simposiuma [Methodological Challenges of Ethnic Cultures: Symposium Materials]. Erevan, Publishing House of the AS of Armenian SSR.

Arutiunov, S.A. (1989). Narody i kul'tura: Razvitie i vzaimodeistvie [Peoples and Cultures: Development and Interaction]. M.

Vlasova, V.B. (1981). Ob isroricheskikh tipakh traditsionnoi orientatsii [On Historical Types of Traditional Orientation], In Sovetskaia etnographiia [Soviet Ethnography], (2).

Markarian, E.S. (2014). Izbrannoe. Nauka o kul'ture i imperativy epokhi [Selected Works. The Science of Culture and Imperative of the Epoch]. Saint Petersburg, Tsentr gumanitarnykh initsiativ Universitetskaia kniga, Moscow.

Markarian, E.S. (1989). Problema tselostnogo issledovania kul'tury v antropologii SShA [The Problem of Comprehensive Study of Culture in the Anthropology of the USA], In Etnologiia $v$ SShA $i$ Kanade [Ethnology in The USA and Canada]. M, Nauka.

Markarian, E.S. (1981). Uzlovye problemy teorii kul'turnoi traditsii [Key Problems of the Cultural Tradition Theory], In Sovetskaia etnographiia [Soviet Ethnography], (2).

Markarian, E.S. (1978). Kul'turnaia traditsiia i zadacha differentsiatsii ee obshchikh i lokal'nykh proiavlenii [Cultural Tradition and the Objective of Its General and Local Manifestations Differentiation], In Metodologicheskie problemy etnicheskikh kil'tur: Materialy simposiuma [Methodological Challenges of Ethnic Cultures: Symposium Materials]. Erevan, Publishing House of the AS of Armenian SSR.

Markarian, E.S. (1978). Ob iskhodnykh metodologicheskikh predposylkakh issledovaniia etnicheskikh kul'tur [On Original Methodological Assumptions of Ethnic Cultures Studies], In Metodologicheskie problemy etnicheskikh kil'tur: Materialy simposiuma [Methodological Challenges of Ethnic Cultures: Symposium Materials]. Erevan, Publishing House of the AS of Armenian SSR.

Markarian, E.S. (1977). Integrativnye tendentsii vo vzaimodeistvii obshchestvennykh $i$ estestvennykh nauk [Integrative Tendencies in the Social and Natural Sciences Interaction]. Erevan, Publishing House of the AS of Armenian SSR.

Sokolov, E.V. (1981). Traditsiia i kul'turnaia preemstvennost' [Tradition and Cultural Succession], In Sovetskaia etnographiia [Soviet Ethnography], (3).

Chistov, K.V. (1981). Traditsiia, "traditsionnoe obshchestvo" i problema var'irovaniia [Tradition, "Traditional Society" and the Problem of Variability], In Sovetskaia etnographiia [Soviet Ethnography], (2). 
Sztompka, P. (1996). Sotsiologiia sotsial'nykh izmenenii [The Sociology of Social Change]. M, Aspekt-Press.

Eisenstadt, Sh. (1973). Tradition, Change, and Modernity. New York, Sydney, Toronto: John Wiley.

Eisenstadt, Sh. (1992). Frameworks of the Great Revolutions: Culture, Social Structure, History and Human Agency, In International Social Science Journal, (44) 133.

Markarian, E.S. (1992) Tradition as an Object of System Study, In World Futures, (34).

Markarian, E. (1998). Capacity for World Strategic Management. Yerevan, Gitutgun.

Redfield R. (1956). Peasant Society and Culture: An Anthropological Approach to Civilisation. Chicago.

Riggs, F. (1964). Administration in Developing Countries: The Theory of Prismatic Society. Boston, Houghton Mifflin Co.

Rudolph, L., Rudolph, S. (1967). The Modernity and Tradition: Political Development in India. Chicago, London, University of Chicago Press.

Royce, A.P. (1982). Ethnic Identity: Strategies of Deversity. Bloomington.

Shils, E. (1961). Centre and Periphery, In Polanyi M. (ed.). The Logic of Personal Knowledge: Essays. London: Routledge \& Kegan Paul.

Shils, E. (1981). Tradition. London; Boston.

\title{
Традициология Э.С. Маркаряна: \\ отличие от зарубежных теорий традиции
}

\author{
С.В. Лурье \\ Соииологический институт РАН \\ Россия, 190005, Санкт-Петербург, \\ ул. 7-я Красноармейская, 25/14
}

\begin{abstract}
В статье рассматривается традиииология Э.С. Маркаряна на фоне зарубежных теорий традиции Р. Редфильда, А. Райс, Э. Шилза, Ш. Эйзенитадта. Все западные авторы, писавшие о традиции, так или иначе мыслят с учетом дихотомии «традиция-модернизация», для отечественных ученых это совершенно не характерно. Традиция для них сама является механизмом развития любого общества. Теория традиции Ш. Эйзенштадта так же, как и традициология Э.С. Маркаряна, предполагает изменчивость традиции, наличие в ней креативной составляющей. Различие состоит в том, что у Маркаряна традиция сама в себе имеет механизм саморазвития, иразвитие являетсяестественным свойством традиции и выступает, в свою очередь, механизмом развития общества. Традиииология Маркаряна описывает мир изменчивый по своей сути, и консервативной составляющей традиции в работах Маркаряна уделяется значительно меньшее внимание. Маркарян тесно связывает традиииологию со своей теорией адаптации и деятельностным подходом в культурологии. Традиииология Маркаряна удобна в качестве теоретического обоснования инструментария этнологии, позволяющего наблюдать, что в культуре является неизменным, а что меняется и как. В статье также рассматривается история возникновения советской и российской традициологии.

Ключевые слова: традициология, дихотомия «традиция-модернизация», исторический стиль, консервативная и креативная составляющие традиџи, новация, инновация, саморазвитие, теория адаптации, деятельностный подход.
\end{abstract}

Научная специальность: 24.00.00-культурология. 